\title{
ВПЛИВ ЛАБОРАТОРНОЇ СХОЖОСТІ НА ВРОЖАЙНІСТЬ ТА ПОСІВНІ ЯКОСТІ ПШЕНИЦІ ОЗИМОЇ В УМОВАХ ПІВНІЧНО-СХІДНОГО ЛІСОСТЕПУ УКРАЇНИ
}

\author{
Оничко Віктор Іванович \\ кандидат сільськогосподарських наук, доцент \\ Сумський національний аграрний університет, м. Суми, Україна \\ ORCID: 0000-0003-0584-319X \\ onichko@gmail.com \\ Оничко Тетяна Олександрівна \\ старший викладач \\ Сумський національний аграрний університет, м. Суми, Україна \\ ORCID: 0000-0003-0411-1157 \\ onychko@gmail.com
}

В статmі наведено результати дослідження щодо визначення закономірностей формування продуктивності посіву пшениці озимої та посівної якості насіння залежно від різної лабораторної схожості насіннєвого матеріалу. Встановлено, що використання насіннєвого матеріалу із різною лабораторною схожістю впливало на повноту появи сходів пшениці озимої - коливання по варіантах дослідження було від 90 до 92 \%. Дещо вищі показники були на варіанті із висівом насіння з 85 \% схожістю - 92 \% при цьому густота рослин складала $413 \mathrm{~mm} / \mathrm{M}^{2}$. Проведений облік густоти рослин пшениці озимої на період збирання показав, що даний показник був вищим на контрольному варіанті зі стандартною лабораторною схожістю 92 \% густота продуктивного стеблостою склала $704 \mathrm{~mm} / \mathrm{M}^{2}$ за коефріцієнта кущення 1,72.

За роки досліджень індивідуальна продуктивність рослин пшениці озимої сорту Достаток значно варіювала під впливом фракторів, що були поставленні на вивчення. Більшу кількість зерен у колосі сфрормували рослини на варіанті із лабораторною схожістю 85 \% - 43,7 шт./колос. Більш ваговите зерно (маса 1000 зерен) було отримано на контрольному варіанті з лабораторною схожістю 92 \% - 43,7 г. Аналіз даних врожайності дозволив виявити зворотну лінійну залежність врожайності зерна від лабораторної схожості висіяного насіння, при цьому коефріцієнт детермінації склав 0,99. Встановлено, що сівба насінням пшениці озимої зі стандартною схожістю $92 \%$ дозволяє, в середньому за трирічними даними, сформувати врожайність зерна на рівні 7,41 m/2а, що на 0,03 m/2а більше у порівнянні із варіантом де висівали насіння з лабораторною схожістю 85 \% і 0,07 m/2a - зі схожістю 80 \%. Слід вказати на той факт, що різниця між врожайністю на досліджуваних варіантах була не суттєвою.

Вивчався вплив висіву насіння із різною лабораторною схожістю на посівні якості зібраного врожаю після його очистки. Характер зміни лабораторної схожості зібраного зерна за результатами аналізу був аналогічний енергї проростання. Слід зауважити, що на всіх варіантах дослідження схожість зібраного зерна була вище стандартної $92 \%$.

Ключові слова: пшениця озима, насіння, схожість, посівні якості, густота рослин, врожайність.

DOI https://doi.org/10.32845/agrobio.2021.2.6

Вступ. На сучасному етапі розвитку людства найбільш важливою проблемою сільськогосподарського виробництва $€$ забезпечення населення країн продовольством. Суттєва роль у вирішенні цієї задачі належить пшениці озимій, яка як в Україні, так і в багатьох країнах $€$ головною зерновою культурою. Проте продуктивність і валові збори зерна цієї культури залишаються нестабільними упродовж років вирощування. За прогнозами "IFA Agriculrural Conference of Managing Plant Nutrition", здійсненими в 1999 р., пшениця в 2015-2030 рр. залишатиметься однією з домінуючих культур (Fertilizer Requirement in 2015 to 2030 (2000)).

Основними проблемами України як на внутрішньому, так і на зовнішньому ринках, є стабілізація виробництва зерна та підвищення його конкурентоспроможності (Müller, 2016; Lebíd' \& Shevchenko, 2008; Poperelja et al., 2003).

Важлива роль у підвищенні врожайності та поліпшенні якості зерна і насіння належить технології вирощування. Завдяки правильному регулюванню агротехнічних факторів вирощування пшениці фрормується структура її посівів з оптимальною кількістю продуктивного стеблостою на одиниці площі, яка забезпечує найвищий урожай високоякісного зерна і насіння (Gyrka, 2016; Tsyliuryk, 2017). Серед таких фракторів $€$ і використання високоякісного насіннєвого матеріалу (Shaporyns'ka, 2005). Згідно чинного стандарту Насіння сільськогосподарських культур сортові та посівні якості ДСТУ 2240-93 «Насіння сільськогосподарських культур сортові та посівні якості», посівні якості насіння зернових культур визначаються наступними показниками: чистотою (вміст основного насіння), схожістю, вологістю, рівнем ураження хворобами та заселення шкідниками (DSTU 2240-93, 1994).

Для створення високопродуктивного посіву пшениці озимої важливо сфрормувати оптимальну густоту рослин і особливо рівномірно розмістити їх на площі (Rocha et al., 2018). Адже, для нормального росту і розвитку рослинам потрібна відповідна площа живлення, за якої вони будуть мати достатню кількість поживних речовин і води для створення необхідної вегетативної 
маси та формування зерна (Romanenko et al., 2009; Netis, 2004; Vozhegova et al., 2013). Зміна густоти посіву пшениці впливає на кінцевий врожай через зміну кількості пагонів і призводить до зміни складових врожайності (Silveira et al., 2010, Geleta T. (2017)). Поряд з цим слід вказати на те, що на зріджених посівах збільшується ймовірність появи бур'янів (Van Der Meulen A., Chauhan B. S. (2017)). Крім того, густота посіву призводить до морфофрізіологічних змін рослин, які можуть в подальшому вплинути на їх ріст та розвиток і як результат на врожай і якість насіння (Abati et al., 2018; Tavares et al., 2014). Насіння, яке має високу фізіологічну якість має покращену швидкість проростання, появи сходів і початковий ріст рослин у полі (Finch-Savage \& Bassel, 2016), що сприяє покращенню посівів і сприяє підвищенню врожайності (Scheeren et al., 2010). За даними Carolina Pereira Cardoso та інших (2021) підвищення густоти посіву сприяє росту врожайності зерна, але знижує життєздатність і схожість насіння.

Змінюючи густоту посіву через вплив на схожість змінюється кількість фоотоассимілятів у рослині (Petter et al., 2016) i, таким чином, будова і фізіологічний потенціал насінини. Насіння різної схожості та різних сортів за однакової густоти сівби показують різні результати у спроможності до кущення, польової схожості, накопичення врожаю і в кінцевому - якості насіння (Abati et al., 2017). Таким чином, сівба насінням з різною лабораторною схожістю і особливо рівномірність їх розміщення у рядку може призвести до зміни фрізіологічного потенціалу посіву.

Мета дослідження - встановлення закономірностей формування врожайності пшениці озимої та посівної якості насіння залежно від різної лабораторної схожості насіннєвого матеріалу.

Матеріали і методи досліджень. Дослідження проводились в Сумському національному аграрному університеті упродовж 2017-2019 років. Метеорологічні умови впродовж років досліджень суттєво вплинули на ріст і розвиток рослин пшениці озимої, і в кінцевому результаті на їх рівень врожайності. Це дозволило більш повно виявити ефективність досліджуваних фракторів.

Дослідження проводили на сорті пшениці озимої Достаток селекції Миронівського інституту пшениці імені В. М. Ремесла НААНУ та Інституту фрізіології рослин і генетики НАНУ.

Досліди закладались і проводились згідно методики державного сортовипробування сільськогосподарських культур, методичних вказівок щодо проведення польових досліджень і вивчення технології вирощування зернових культур (Інститут землеробства УААН, 2001 р.) і методики польових досліджень (Dospehov, 1985).

Визначення посівних якостей насіння проводили згідно ДСТУ 4138-2002 "Насіння сільськогосподарських культур. Методи визначення якості" та ДСТУ 2240-93 "Насіння сільськогосподарських культур. Сортові та посівні якості. Технічні умови".

Польові досліди закладалися за наступною схемою: 1. Контроль - схожість насіння лабораторна 92 \%,
2. Схожість насіння лабораторна $85 \%$, 3. Схожість насіння лабораторна 80 \%. Вагова норма висіву із розрахунку на $100 \%$ схожість насіння при кількісній нормі висіву 4,5 млн. шт. схожих насінин/га складала по варіантах : 1. - 197 кг/га, 2. - 213 кг/га, 3. - 226 кг/га. Агротехніка та догляд за посівами пшениці озимої загальноприйнята для зони північно-східного Лісостепу України.

Результати. Одним із показників, який є складовою продуктивності посіву є густота рослин. Слід відмітити, що в роки досліджень, температурні умови були сприятливими для появи своєчасних сходів, що не можна сказати про зволоження ґрунту, яке було недостатнім. Тому настання фази повних сходів коливалось від 16 до 24 днів залежно від років досліджень. За результатами наших досліджень використання насіннєвого матеріалу із різною лабораторною схожістю впливало на повноту появи сходів пшениці озимої - коливання по варіантах дослідження було від 90 до 92 \% (рис. 1). Дещо вищі показники були на варіанті із висівом насіння з $85 \%$ схожістю - 92\% при цьому густота рослин складала 413 шт/M².

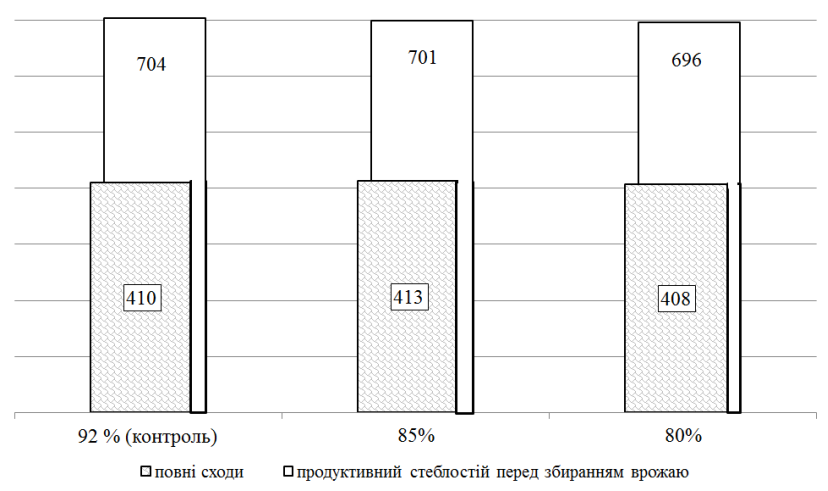

Рис. 1. Динаміка формування густоти рослин у посівах залежно від лабораторної схожості висіяного насіння, шт./м²

Проведений облік густоти рослин пшениці озимої на період збирання показав, що даний показник суттєво варіював по варіантах досліджень. Так, на контрольному варіанті зі стандартною лабораторною схожістю 92 \% густота продуктивного стеблостою склала 704 шт./м² за коефіцієнта кущення 1,72. Найнижча густота продуктивного стеблостою була на варіанті із лабораторною схожістю 80 \% 696 шт./М².

Поряд із кількістю рослин на одиниці площі одним із основних елементів формування величини врожаю $€$ їх індивідуальна продуктивність. За роки досліджень індивідуальна продуктивність рослин пшениці озимої сорту Достаток значно варіювала під впливом факторів, що були поставленні на вивчення (табл. 2). Так, більшу кількість зерен у колосі сформували рослини на варіанті із лабораторною схожістю 85\%-43,7 шт./колос. Більш виповнене зерно (маса 1000 зерен) було отримано на контрольному варіанті 3 лабораторною схожістю 92\%-43,7 г. На інших варіантах прояв даного показника був нижчим на 1,0-1,1 г. 


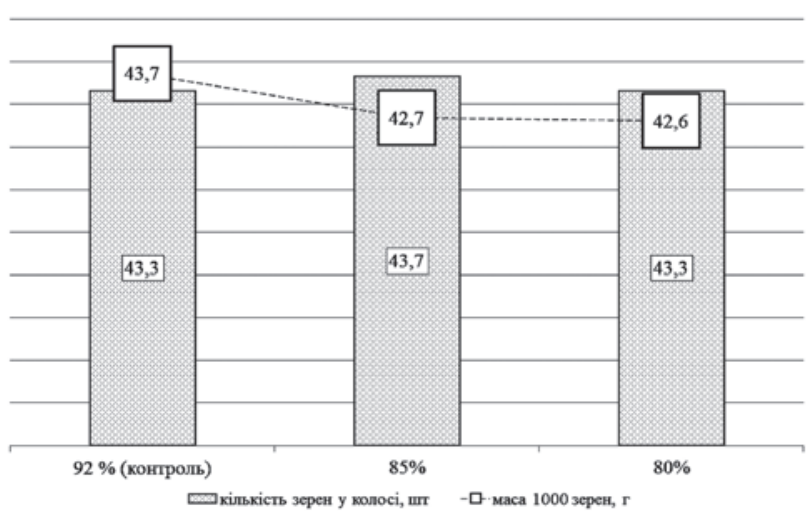

Рис. 2. Формування індивідуальної продуктивності рослин пшениці озимої залежно від лабораторної схожості висіяного насіння

Аналіз даних врожайності дозволив виявити прямолінійну залежність врожайності зерна від лабораторної схожості висіяного насіння, при цьому коефріцієнт детермінації склав 0,99 (рис. 3).

Встановлено, що сівба насінням пшениці озимої зі стандартною схожістю $92 \%$ дозволяє, в середньому за трирічними даними, сформувати врожайність зерна на рівні 7,41 т/га, що на 0,03 т/га більше у порівнянні із варіантом де висівали насіння 3 лабораторною схожістю 85 \% і 0,07 т/га - зі схожістю 80 \%. Слід вказати на той факт, що різниця між врожайністю на досліджуваних варіантах була не суттєвою.

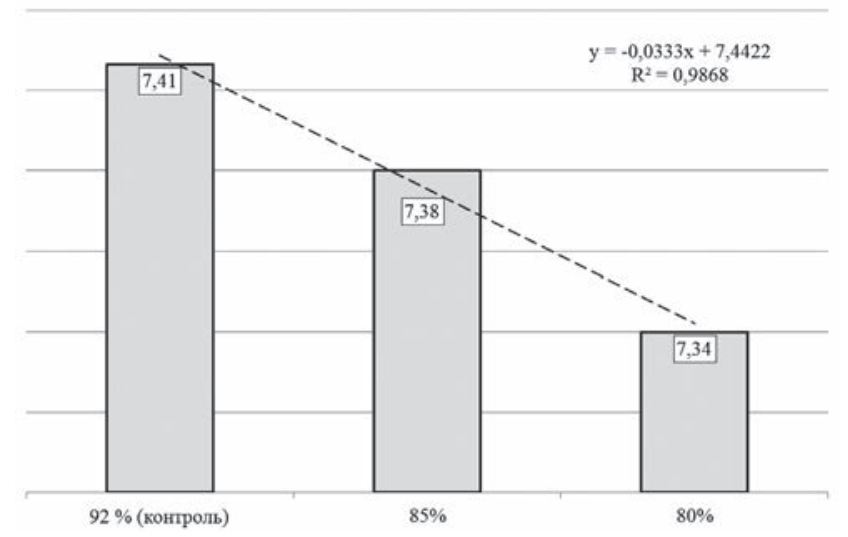

Рис. 3. Врожайність зерна пшениці озимої сорту Достаток залежно від лабораторної схожості висіяного насіння, т/га

Поряд із вивченням впливу норми висіву насіння із різною лабораторною схожістю на показники продуктивності, нами було досліджено посівні якості зібраного врожаю після його очистки відповідно до вимог Державного стандарту (рис. 4).

Як видно, на контрольному варіанті (лабораторна схожість 92 \%) енергія проростання була 92,7 \% і була

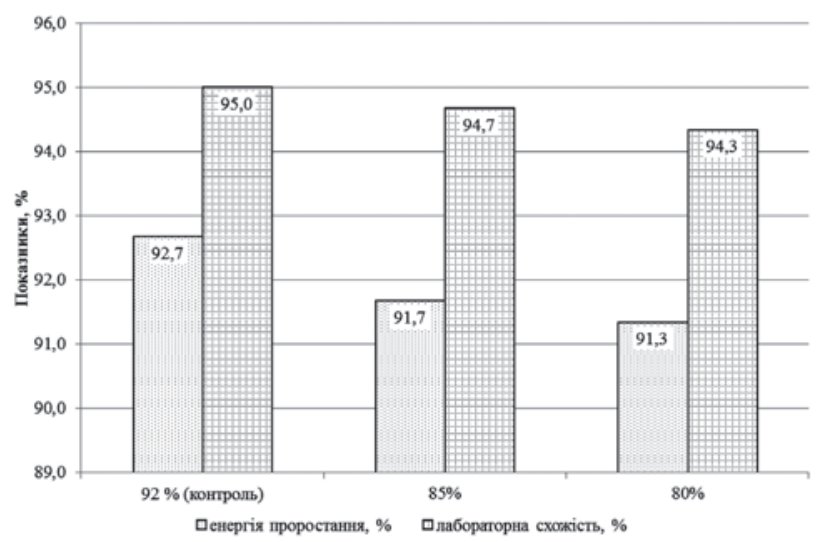

Рис. 4. Вплив лабораторної схожості на посівні якості насіння в наступній репродукції

більшою на 1,0-1,4 \%, порівняно 3 іншими варіантами дослідження.

Характер зміни лабораторної схожості зібраного зерна за результатами аналізу був аналогічний енергії проростання. Так, на контрольному варіанті схожість склала $95 \%$, на інших варіантах вона була нижчою на 0,3-0,7 \%. Слід зауважити, що на всіх варіантах дослідження схожість зібраного зерна була вище стандартної $92 \%$.

Обговорення. 3 огляду на результати наших досліджень, можна частково погодитись з думками інших вчених щодо важливої ролі лабораторної схожості, що виступає головним чинником під час віднесення тієї чи іншої партії до кондиційного або ж некондиційного насіння (Avdonina, 2003; Donec', 2007, Strona, 1966) Отримані нами результати досліджень вказують на те, що межа мінімальної лабораторної схожості для насіння пшениці в $92 \%$ не може бути вердиктом відмови у використанні цього насіння для сівби.

Що стосується отримання суттєвих приростів врожаю пшениці озимої, Н. Я. Кирпа у своїх дослідженнях зазначає, що насіння з високими посівними якостями дозволяє збільшити приріст урожаю більш ніж на $30 \%$. По мірі збільшення показника схожості насіння якість поліпшується. Це проявляється у підвищенні продуктивності та урожайності рослин (Kyrpa, 2011, Cardoso et al., 2021).

Результатами наших досліджень також підтверджено вплив лабораторної схожості на врожайність зерна пшениці озимої, але він був на порядок меншим. Нами не було виявлено залежності польової схожості від показників лабораторної схожості.

Висновки. В результаті проведених досліджень встановлено, що посіви із вищими показниками схожості насіння, формують більшу врожайність зерна, ніж посіви із насіння, що не відповідає ДСТУ за схожістю насіння. Виявлено зворотну лінійну залежність врожайності зерна пшениці озимої і лабораторної схожості висіяного насіння.

Незважаючи на сівбу насінням з пониженими показниками лабораторної схожості, такі посіви формують зерно з лабораторною схожістю вище стандартної $92 \%$.

\section{Бібліографічні посилання:}

1. Fertilizer Requirement in 2015 to 2030 (2000). Imphos : Phosphate newsletter, 12, 4-5.

2. Müller, D., Jungandreas, A., Koch, F., \& Schierhorn, F. (2016) Impact of Climate Change on Wheat Production in Ukraine. Agricultural Policy Report. Kyiv, 41. 
3. Lebíd,' Ê. M., \&Shevchenko, M. S. (2008) Scientific foundations and evaluation of the effectiveness of grain production in Ukraine. Dnípropetrovs'k: Ínstitut zernovogo gospodarstva, 33-34, 3-7.

4. Poperelja, F., Chervonis, M., \& Lytvynenko, M. (2003) Strategy for the cultivation and use of Ukrainian wheat in market conditions. Prypozycija, 5, 10-13.

5. Gyrka, A. D. (2016) Features of realization the productivity potential of winter and spring wheat varieties in northern steppe of Ukraine. Bjuleten' Instytutu sil's'kogo go spodarstva stepovoi' zony NAAN Ukrai'ny, 11, 27-30.

6. Tsyliuryk, A. I., Tkalich, Yu. I., Masliiov, S. V., \& Kozechko, V. I. (2017) Impact of mulch tillage and fertilization on growth and development of winter wheat plants in clean fallow in Northern Steppe of Ukraine. Ukrainian Journal of Ecology, 7(4), 511-516. doi: 10.15421/2017_153.

7. Shaporyns'ka, N. M. (2005) Productivity and quality of grain and seeds of winter soft and durum wheat varieties depending on growing conditions in the south of Ukraine: Avtoref. dys... kand. s.- g. nauk: 06.01.09. Hersons'kyj derzh. agrarnyj un-t. Herson. 16.

8. DSTU 2240-93. Agricultural seeds. Varietal and sowing qualities. Tehnichni umovy. K.: Derzhstandart Ukrai'ny, $1994,73$.

9. Romanenko, O. L., Rybka, V. S., Kompanijec', V. O., \& Kulyk, A. O. (2009) Agrobiological and economic issues of growing modern varieties of winter wheat in the southern Steppe of Ukraine. Bjul. In-tu s. g. step. zony NAANU, 37.

10. Netis, I. T. (2004). Winter wheat in the Steppe zone. Ajlant, Herson, 95.

11. Vozhegova, R., Zajec', S., \& Kovalenko, A. (2013). Practice shows that little moisture in the South Steppe zone can be compensated by placing winter wheat over black fallow. Zerno i hlib, 4, 36-38.

12. Silveira, G. D., Carvalho F.I.F.D., Oliveira, A.C.D., Valério, I.P., Benin, G., Ribeiro, G., Crestani M., Luche, H.D.S., \& Silva, J.A.G.D. (2010) Efeito da densidade de semeadura e potencial de afilhamento sobre a adaptabilidade e estabilidade em trigo. Bragantia, 69(1), 63-70.

13. Geleta, T. (2017) Vliyaniye normy vyseva i metoda poseva na kachestvo semyan sortov myagkoy pshenitsy (Triticum Aestivum L.) v rayone Khoro, zapadnaya Efiopiya. Malaziyskiy zhurnal meditsinskikh i biologicheskikh issledovaniy, 4(2), 117-128. doi: 10.18034/mjmbr.v4i2.436.

14. Abati, J., Brzezinski, C. R., Zucareli, C., Foloni, J. S. S., \& Henning, F. A. (2018) Growth and yield of wheat in response to seed vigor and sowing densities. Revista Caatinga, 31(4), 891-899. doi: 10.1590/1983-21252018v31n411rc.

15. Tavares, L.C.V., Foloni, J.S.S., Bassoi, M.C., \& Prete, C.E.C. (2014). Genótipos de trigo em diferentes densidades de semeadura. Pesquisa Agropecuária Tropical, 44(2), 166-174.

16. Finch-Savage, W. E., \& Bassel, G. W. (2016) Seed vigour and crop establishment: extending performance beyond adaptation. Journal of Experimental Botany, 67(3), 567-591.

17. Scheeren, B. R., Peske, S. T., Schuch, L. O. B., \& Barros, A.C.A. (2010) Qualidade fisiológica e produtividade de sementes de soja. Revista Brasileira de Sementes, Londrina, 32(3), 35-41.

18. Petter, F. A., Silva, J. A. D., Zuffo, A. M., Andrade, F. R., Pacheco, L. P., \& Almeida, F. A. D. (2016). Elevada densidade de semeadura aumenta a produtividade da soja? Respostas da radiação fotossinteticamente ativa. Bragantia, 75(2), 173-183.

19. Van Der Meulen, A., \& Chauhan, B. S. (2017) A review of weed management in wheat using crop competition. Crop Protection, 95, 38-44, doi: 10.1016/j.cropro.2016.08.004/

20. Abati, J., Brzezinski, C. R., Foloni, J. S., Zucareli, C., Bassoi, M. C., \& Henning, F. A. (2017) Seedling emergence and yield performance of wheat cultivars depending on seed vigor and sowing density. Journal of Seed Science, 39(1), 58-65.

21. Methodical instructions for conducting field research and studying the technology of growing grain crops. (2001). Chabany : Instytut zemlerobstva UAAN, 22.

22. Dospehov, B. A. (1985). Field experiment technique (with the basics of statistical processing of research results). 5-e yzd., dop. y pererab. M. : Agropromyzdat, 351.

23. DSTU 4138-2002. Agricultural seeds. Terms and Definitions. Derzhstandart Ukrai'ny, Kyiv, 2003, 173.

24. Avdonina N. S. (2003). The value of the absolute weight of seeds in the size and quality of the wheat crop. Zbirnyk naukovyh prac' MNDIP im. M. V. Remesla, 56-61.

25. Donec', M. M. (2007). Seed breeding with the basics of breeding: a tutorial. Agrarna nauka, Kyiv, 337.

26. Strona, Y. G. General seed science of field crops. M. : Kolos, 1966. 464.

27. Kyrpa, N. Ja. (2011). A moment before sowing (about seed quality). Zerno, 3, 106-109.

28. Carolina Pereira Cardoso, José Henrique Bizzarri Bazzo, Jéssica de Lucena Marinho, Claudemir Zucareli (2021) Effect of seed vigor and sowing densities on the yield and physiological potential of wheat seeds. Journal of Seed Science, 43, e202143002, 1-11. doi: 10.1590/2317-1545v43241586.

Onychko V. I., PhD (Agricultural Sciences), Associate Professor, Sumy National Agronomy University, Sumy, Ukraine

Onychko T. O., Senior Lecturer, Sumy National Agrarian University, Sumy, Ukraine

The influence of laboratory germination on the yield and sowing qualities of winter wheat in the conditions of the north-eastern Forest-Steppe of Ukraine

The article presents the results of a study on determining the regularities of the formation of winter wheat sowing productivity and the sowing qualities of seeds, depending on the different laboratory germination of seed material. It was found that the use of seed material with different laboratory germination affects the completeness of winter wheat seedlings fluctuations in the research options were from 90 to $92 \%$. Slightly higher rates were on the variant with seed sowing of $85 \%$ germination rate $-92 \%$, while the plant density was $413 \mathrm{pcs} / \mathrm{m} 2$. The conducted accounting of the density of winter wheat plants during the harvesting period showed that this indicator was higher in the control variant with a standard laboratory germination of $92 \%$, the density of productive stalk was $704 \mathrm{pcs} / \mathrm{m} 2$ with a tillering coefficient of 1.72 . 
Over the years of research, the individual productivity of winter wheat plants of the Dostatok variety varied significantly under the influence of factors that were put to study. A larger number of grains in an ear was formed by plants with a laboratory germination rate of $85 \%-43.7$ pcs/ear. A heavier grain (1000 grain weight) was obtained in the control variant with a laboratory germination rate of $92 \%-43.7 \mathrm{~g}$. The analysis of the yield data made it possible to reveal the linear dependence of the grain yield on the laboratory germination of the sown seeds, while the coefficient of determination was 0.99. It was found that sowing with winter wheat seeds with a standard similarity of $92 \%$ allows, on average, according to three-year data, to form grain yield at the level of $7.41 \mathrm{t} / \mathrm{ha}$, which is $0.03 \mathrm{t} / \mathrm{ha}$ more compared to the option where seeds were sown with laboratory similarity of $85 \%$ and 0.07 tha - with $80 \%$ similarity. It should be pointed out that the difference between the yields on the studied variants was not significant.

The effect of sowing seeds with different laboratory germination rates on the sowing qualities of the harvested crop after cleaning was studied. The nature of changes in the laboratory germination of the harvested grain according to the analysis results was similar to the germination energy. It should be noted that in all variants of the study, the similarity of the harvested grain was higher than the standard $92 \%$.

Key words: winter wheat, seeds, germination, sowing qualities, plant density, productivity. 